\title{
Rola leczenia miejscowego chorych na raka piersi w IV stopniu zaawansowania - przegląd piśmiennictwa
}

\author{
Elżbieta Nowicka, Rafał Tarnawski
}

Rak piersi w stadium pierwotnego rozsiewu odległego stanowi ok. $6 \%$ wszystkich raków piersi. Rokowanie dla tych chorych jest niekorzystne, a leczenie jest prowadzone z intencją paliatywną. Podstawą leczenia tej grupy chorych jest leczenie systemowe oparte na chemioterapii, hormonoterapii i immunoterapii. Chirurgiczne leczenie miejscowe lub radioterapia ogniska pierwotnego stosowane są głównie w celu łagodzenia objawów klinicznych towarzyszących guzowi pierwotnemu. Krótkie przeżycia chorych oraz charakter paliatywny leczenia nie uzasadniały decyzji o agresywnym leczeniu miejscowym guza pierwotnego. Doniesienia z literatury ostatnich lat wykazały istotny wpływ zarówno miejscowego leczenia operacyjnego, jak i samodzielnej radioterapii na przeżycia chorych na raka piersi z synchronicznymi przerzutami. Celem pracy jest przedstawienie aktualnej wiedzy na temat roli leczenia miejscowego u chorych na raka piersi w stadium synchronicznego rozsiewu oraz próba odpowiedzi na pytanie o zasadność zmiany w podejściu do leczenia miejscowego tej grupy chorych.

\section{A literature review of the role of local treatment in metastatic breast cancer patients}

Epidemiological data indicate that $6 \%$ of women are diagnosed with breast cancer with distant metastases at initial presentation. The survival for these patients is poor and the treatment is palliative. Therapy is based on systemic chemotherapy, hormonal therapy and immunotherapy. Local treatment is mainly recommended to prevent or relief symptoms but it is traditionally considered to have no impact on survival. The poor prognosis and palliative idea of therapy do not justify aggressive local treatment. Several studies indicate that local treatment of the primary tumour by both surgery and radiotherapy may improve survival for metastatic breast cancer patients. Hence maybe it is now time to reconsider the role of local therapies for this group of patients. The main objective of this review is to highlight current knowledge of local therapy of the primary tumour for breast cancer patients with synchronous distant metastases. We try to assess clinical practice in the local therapy of the primary tumour in metastatic breast cancer patients.

NOWOTWORY Journal of Oncology 2014; 64, 2: 180-186

Słowa kluczowe: uogólniony rak piersi, leczenie miejscowe, leczenie operacyjne, radioterapia

Key words: metastatic breast cancer, local therapy, surgery, radiotherapy

Rak piersi w stadium pierwotnego rozsiewu odległego stanowi ok. $6 \%$ wszystkich raków piersi [1, 2]. Jest to heterogenna grupa chorych o różnym obrazie klinicznym, od pojedynczych ognisk przerzutów do wieloogniskowego, rozległego zajęcia narządów odległych, różniących się dynamiką. Na podstawie rejestrów SEER z roku 2007 stanowił on $5 \%$ wszystkich zachorowań, co przełożyło się na bezwzględ- na liczbę 12600 chorych [1, 2]. W rejestrach europejskich odsetek ten wynosi $6 \%$ [3-5]. W roku $2000 \mathrm{w}$ rejestrach województwa śląskiego stwierdzono 101 zachorowań na pierwotnie uogólnionego raka piersi, co stanowiło 6,8\% wszystkich zachorowań [6].

Pięcioletnie przeżycia tej grupy chorych wynoszą ok. $25 \%$ [1, 3]. Średnie przeżycia pacjentek plasują się w prze-

III Klinika Radioterapii i Chemioterapii

Centrum Onkologii — Instytut im. Marii Skłodowskiej-Curie, Oddział w Gliwicach 
dziale 16-26 miesięcy [7, 8] i są zależne od szeregu cech klinicznych, w tym liczby i lokalizacji przerzutów, oraz patologicznych - np. statusu receptorów steroidowych i receptora HER. Mimo odpowiedzi na leczenie do progresji choroby dochodzi średnio po 12-24 miesiącach. Obserwacje ostatnich lat wskazują na wzrost przeżyć o ok. 1-2\% rocznie, co niewątpliwie jest zasługą nowoczesnych schematów leczenia systemowego, ale z pewnością znaczenie ma również fakt wykrywania choroby przerzutowej we wczesnym etapie, w bezobjawowym okresie choroby, z możliwym większym efektem leczenia systemowego [7, 8]. Porównanie wyników leczenia chorych w zależności od okresu leczenia: 1987-1993 vs 1994-2000 wykazało poprawę średnich przeżyć z 23 do 29 miesięcy, a 5-letnie przeżycia całkowite odpowiednio wyniosły 11 i $28 \%$ [8].

Częstość rozpoznań bezobjawowych przerzutów w raku piersi uzależniona jest od metody badań obrazowych wykorzystanych do ich wykrycia. Średnio rozpoznaje się je u 7\% chorych [9]. Przy wykorzystaniu klasycznych badań radiologicznych odsetek ten wynosi nieco ponad 2\%, przy użyciu PET-CT wzrasta do ok. 10\%, a gdy użyje się obydwu metod sięga on 31\%. Znaczenie ma również stopień zaawansowania guza pierwotnego. W I ill stopniu zaawansowania i gdy wykorzystano klasyczne badania, rozsiew rozpoznawany jest rzadko, w zakresie 0,2-1,2\%. Dla chorych w III stopniu zaawansowania odsetek wzrasta do 13,9\%, a w przypadku zapalnej postaci raka i przy wykorzystaniu badania PET-CT przerzuty odległe stwierdza się u ok. 40\% chorych [9].

Chore na raka piersi w IV stopniu zaawansowania leczone są paliatywnie, którego założeniem jest wydłużenie życia i troska o jego jak najwyższą jakość. Podstawą leczenia tej grupy chorych jest leczenie systemowe oparte o chemioterapię, hormonoterapię i immunoterapię. Chirurgiczne leczenie miejscowe lub radioterapia ogniska pierwotnego stosowane są głównie w celu łagodzenia objawów klinicznych towarzyszących guzowi pierwotnemu [7, 10]. Krótkie przeżycia chorych, brak wpływu na przeżycia oraz charakter paliatywny leczenia nie uzasadniają decyzji o agresywnym leczeniu miejscowym guza pierwotnego, chociaż u znacznej części chorych na pierwotnie uogólnionego raka piersi zaawansowanie guza i przerzuty węzłowe pozwalają na przeprowadzenie „radykalnego" leczenia miejscowego [7]. W rejestrach amerykańskich odsetek chorych leczonych miejscowo wynosi ok. 50\% [7].

Celem pracy jest przedstawienie aktualnej wiedzy na temat roli leczenia miejscowego u chorych na raka piersi w stadium synchronicznego rozsiewu oraz próba odpowiedzi na pytanie o zasadność zmiany w podejściu do leczenia miejscowego w tej grupie chorych. W piśmiennictwie ostatnich kilku lat pojawiło się wiele publikacji, w których autorzy podjęli próbę oceny wpływu zarówno miejscowego leczenia operacyjnego, jak i radioterapii na przeżycia chorych na raka piersi w IV stopniu zaawansowania klinicznego [3-5].
W badaniach retrospektywnych przeanalizowano przebieg kliniczny i wyniki leczenia chorych z dużych rejestrów (SEER, EUROCARE) oraz rejestrów szpitalnych w okresie od 1988 do 2003 roku $[3,4,11]$. Od $35 \%$ do $60 \%$ chorych w tych opracowaniach zakwalifikowano do leczenia miejscowego, co może być wyrazem zmiany w podejściu do leczenia tej grupy chorych mimo braku wyników badań randomizowanych, które potwierdzałyby korzystny wpływ leczenia miejscowego na przeżycia [3, 4, 7, 10-13]. Wybrane publikacje przedstawiono $w$ tabeli I [4].

\section{Podstawy teoretyczne}

Usunięcie ogniska pierwotnego w przypadku rozsianego procesu nowotworowego prowadzi do poprawy wyników leczenia w wielu nowotworach, np. w raku nerki, raku odbytnicy, czerniaku złośliwym i raku jajnika [4]. W badaniach randomizowanych wykazano statystycznie dłuższe przeżycia u chorych na uogólnionego raka nerki, u których wykonano nefrektomię [4, 14]. Nasuwa się pytanie, czy jest również podobnie u chorych na raka piersi. Biorąc pod uwagę odmienne cechy kliniczno-patologiczne nowotworów, nie jest możliwe bezpośrednie porównanie wyników badań oceniających wpływ leczenia miejscowego na przeżycia w różnych nowotworach, jednak kilka mechanizmów biologicznych może tłumaczyć korzystny efekt leczenia miejscowego guza pierwotnego. Istnieje teoria, że guz pierwotny jest źródłem rozsiewu, dlatego wraz z usunięciem guza eliminujemy główny rezerwuar komórek nowotworowych. Zmniejszenie liczby komórek nowotworowych oraz usunięcie martwiczych tkanek guza może zwiększać skuteczność chemioterapii, również zmniejszając ryzyko powstania szczepów chemioopornych [15]. Szereg obserwacji klinicznych potwierdza znaczenie liczby krążących komórek nowotworowych jako niezależnego czynnika odpowiedzi na leczenie chorych na raka piersi w stadium rozsiewu [16, 17]. W wielu nowotworach, w tym i w raku piersi, guz pierwotny indukuje immunosupresję za pośrednictwem szeregu cytokin $[18,19]$. Usunięcie guza pierwotnego wpływa na poprawę funkcji układu odpornościowego gospodarza [18]. Leczenie miejscowe (chirurgia i radioterapia) zapobiega lokalnemu wzrostowi guza. Wyleczenie niepowodzenia miejscowego może korzystnie wpłynąć na długość przeżycia chorych. Wystąpienie wznowy miejscowej jest niekorzystnym czynnikiem ryzyka progresji choroby [20, 21]. Teoretycznie możliwe są również niekorzystne skutki usunięcia guza pierwotnego poprzez dwa mechanizmy: 1) — eliminacji inhibitorów angiogenezy, co może prowadzić do jej nasilenia, oraz 2) — działania immunosupresyjnego czynników uwalnianych podczas gojenia się rany pooperacyjnej [22].

\section{Leczenie operacyjne}

Leczenie operacyjne jest najczęściej wykorzystywaną metodą leczenia miejscowego. Zbiorcza analiza wyników 
Tabela I. Wybrane retrospektywne badania oceniające wpływ leczenia miejscowego na przeżycia chorych na raka piersi z synchronicznymi przerzutami odległymi [4]

\begin{tabular}{lccccc}
\hline Autor & Ośrodek & Lata & $\begin{array}{c}\text { Rodzaj } \\
\text { leczenia }\end{array}$ & $\begin{array}{c}\text { Liczba chorych/ } \\
\text { /LRT/bez LRT }\end{array}$ & $\begin{array}{c}\text { MVA/OS } \\
\text { HR }\end{array}$ \\
\hline Khan i wsp. & NCD of American College of Surgeons & $1990-1993$ & Chirurgia & $16023 / 9162 / 6861$ & HR OS 0,61 \\
Gnerlich i wsp. & SEER & $1988-2003$ & Chirurgia & $9734 / 4578 / 5156$ & HR OS 0,57 \\
Bafford i wsp. & Dana Faber Cancer Center & $1998-2005$ & Chirurgia & $147 / 61 / 68$ & HR OS 0,47 \\
Shien i wsp. & National Cancer Center & $1962-2007$ & Chirurgia & $326 / 160 / 184$ & HR OS 0,89 \\
Babiera i wsp. & MD Anderson Cancer Center & $1997-2002$ & Chirurgia & $224 / 82 / 142$ & HR OS 0,50 \\
Ruiterkamp i wsp. & Eindhoven Cancer Registry & $1993-2004$ & Chirurgia & $728 / 288 / 440$ & HR OS 0,62 \\
Leung i wsp. & Medical College of Virginia & $1990-2000$ & Chirurgia & $157 / 52 / 105$ & Bez wplywu \\
Fields i wsp. & Washington University Medical Center & $1996-2005$ & Chirurgia & $409 / 287 / 222$ & HR OS = 0,53 \\
Rapiti i wsp. & Geneva Cancer Registry & $1977-1996$ & Chirurgia & $300 / 127 / 173$ & HR OS 0,6 \\
Blanchard i wsp. & Laboratory of University of Texas & $1973-1991$ & Chirurgia & $395 / 242 / 153$ & HR OS = 0,609 \\
Cady i wsp. & Healh Science Center & & & & \\
Le Scodan i wsp. & Massachussetts General Hospital & $1970-2002$ & Chirurgia & $622 / 234 / 388$ & HR OS 0,7 \\
\hline
\end{tabular}

LRT — leczenie miejscowe, bez LRT — bez leczenia miejscowego; MVA — analiza wieloczynnikowa; OS — przeżycia całkowite

wykazała, że prowadzi ono do poprawy przeżyć chorych na pierwotnie uogólnionego raka piersi, co potwierdzono w siedmiu badaniach klinicznych [10, 13]. Największe badanie oceniające rolę leczenia operacyjnego to badanie Khan i wsp., przeprowadzone w grupie 16023 chorych na raka piersi w stadium pierwotnego uogólnienia, leczonych w okresie od 1990 do 1993 r., w której u 9162 chorych przeprowadzono leczenie operacyjne [23]. U 3513 chorych wykonano zabieg operacyjny polegający na częściowej mastektomii, a u 5649 — radykalną amputację. $U$ ponad $60 \%$ zabieg był radykalny mikroskopowo. Przeprowadzenie radykalnego leczenia operacyjnego, tj. z zachowaniem negatywnych marginesów chirurgicznych, prowadziło do zmniejszenia ryzyka zgonu o 39\%. Średni czas przeżycia chorych po radykalnym leczeniu wyniósł 31,9 miesiąca, zaś 19 miesięcy u chorych nieoperowanych. Analiza wieloczynnikowa potwierdziła znaczenie radykalnie wykonanego zabiegu $(\mathrm{HR} 0,75)$ jako niezależnego czynnika rokowniczego dla przeżyć całkowitych [23]. Kolejna praca, tym razem europejska, oparta jest na analizie danych klinicznych 728 chorych leczonych w latach 1993-2003 [24]. 288 chorych leczono operacyjnie, w tym wykonano 189 amputacji, 85 chorych leczono oszczędzająco, a u 14 chorych nie określono rodzaju zabiegu. Mediana czasu przeżycia chorych operowanych była znamiennie dłuższa w porównaniu z chorymi nieleczonymi - 31 miesięcy vs 14 miesięcy, a 5-letnie przeżycia całkowite wyniosły odpowiednio $24,5 \%$ i $13 \%$. Nie stwierdzono różnic w przeżyciach w zależności od rodzaju zabiegu (amputacja vs BCT, $p=0,59$ ). Poszerzenie zakresu leczenia operacyjnego o zabieg w obszarze węzłów chłonnych dołu pachowego nie przyniosło dodatkowego zysku klinicznego $(p=0,35)$. W analizie wieloczynnikowej leczenie operacyjne okazało się być czynnikiem niezależnym rokowniczo dla OS ( $\mathrm{HR}=0,62)$ obok czynników klinicznych takich jak: wiek chorych, liczba ognisk przerzutowych, zastosowanie leczenia systemowego. Młodsze chore, u których rozpoznano pojedyncze ognisko przerzutowe, leczone systemowo oraz operacyjnie miały lepsze rokowanie. Zaawansowanie kliniczne guza pierwotnego, lokalizacja przerzutów (narządy miąższowe vs pozamiąższowe) oraz zastosowanie radioterapii nie miały wpływu na przeżycia [24].

\section{Zakres zabiegu operacyjnego}

W doniesieniach z literatury nie wykazano wpływu rodzaju zabiegu operacyjnego na wyniki leczenia. W pracy Khan i wsp. trzyletnie przeżycia całkowite dla chorych po całkowitej i częściowej mastektomii były porównywalne i wynosiły odpowiednio 34,7\% i 35,7\%, a decydującym okazało się uzyskanie radykalności mikroskopowej zabiegu [23]. Również w pracy europejskiej sam typ zabiegu operacyjnego nie wpływał na wyniki leczenia [24]. Nie stwierdzono różnic w przeżyciach u chorych leczonych z zaoszczędzeniem gruczołu i u chorych poddanych amputacji $(p=0,59)$. Poszerzenie zakresu leczenia operacyjnego o zabieg w obszarze węzłów chłonnych dołu pachowego nie przyniosło dodatkowego zysku klinicznego $(p=0,35)$ [24].

\section{Lokalizacja przerzutów odległych}

W pracy Rapiti i wsp. stwierdzono wydłużenie przeżycia u chorych, u których stwierdzono przerzuty tylko w kościach (HR 0,2; $\mathrm{p}=0,001)$. Nie wykazano wpływu leczenia operacyjnego w przypadku innych lokalizacji rozsiewu (HR 0,7; $p=0,31$ ) [25]. Inni autorzy również wskazują, że chore bez cech rozsiewu do narządów miąższowych odnoszą większy zysk z leczenia chirurgicznego [26]. 


\section{Rola marginesów chirurgicznych}

W dwóch badaniach klinicznych wykazano znaczenie radykalności leczenia operacyjnego [23, 25]. Zysk z zastosowania leczenia operacyjnego w postaci wydłużenia czasu przeżycia całkowitego ograniczony był do chorych, u których uzyskano negatywne marginesy cięcia [23, 25]. W pracy Khan i wsp. trzyletnie przeżycia całkowite chorych, u których uzyskano negatywne marginesy operacyjne, wyniosły $35 \%$ w porównaniu z $26 \%$ u chorych operowanych nieradykalnie, tj. z pozytywnymi marginesami, oraz $17 \%$ u chorych nieoperowanych ( $<<0,001$ ) [23]. W pracy Rapiti i wsp., opartej na analizie 300 chorych z Genewa Cancer Registry, 5-letnie przeżycia całkowite wyniosły $27 \%$ u operowanych radykalnie, $16 \% \mathrm{w}$ przypadku stwierdzenia pozytywnego marginesu cięcia chirurgicznego i 12\% u chorych nieleczonych miejscowo ( $p=0,002)$ [25]. Leczenie operacyjne w przypadku stwierdzenia negatywnych marginesów chirurgicznych prowadziło do zmniejszenia ryzyka zgonu o 40\% w porównaniu z chorymi nieoperowanymi (HR 0,6) [25]. Analiza jednoczynnikowa danych z MD Anderson Cancer Center wskazała na lepsze wyniki w zakresie czasu wolnego od progresji przerzutów w przypadku radykalnego leczenia chirurgicznego guza pierwotnego (- vs + marginesy, $\mathrm{p}=0,013 ; \mathrm{HR} 2,3)$ [27].

\section{Czas wykonania zabiegu operacyjnego}

Optymalny czas przeprowadzenia zabiegu operacyjnego nie jest ustalony. Pojawia się pytanie, czy powinien być przeprowadzony wcześnie, czy po zastosowaniu leczenia systemowego lub tylko jako element leczenia paliatywnego. Z założeń teoretycznych wydaje się, że leczenie operacyjne powinno być wykonane na wczesnym etapie rozsiewu procesu nowotworowego. W pracy Rao R. i wsp. z MD Anderson Cancer Center autorzy podjęli się próby oszacowania optymalnego momentu wykonania zabiegu u 75 chorych. Chore podzielono na trzy grupy w zależności od czasu leczenia operacyjnego: I grupa była leczona w czasie do 3 miesięcy od rozpoznania, II w okresie od 3 do 9 miesięcy, zaś oraz III grupa operowana później niż 9 miesięcy. Wszystkie chore leczone były systemowo w oparciu o chemioterapię z zastosowaniem antybiotyków antracyklinowych lub otrzymywały hormonoterapię. W analizie jednoczynnikowej czynnikami istotnymi dla czasu wolnego od progresji ognisk przerzutowych i dla przeżycia całkowitego były: liczba ognisk przerzutowych, lokalizacja przerzutów oraz leczenie operacyjne $z$ ujemnymi marginesami mikroskopowymi. W analizie wieloczynnikowej jedynie chore z mniejszą liczbą ognisk (1 vs > 1, HR 2,6) oraz u których leczenie miejscowe było radykalne (- vs + marginesy, HR 2,3), miały istotnie dłuższy czas wolny od progresji. Czas wykonania zabiegu operacyjnego nie miał wpływu na długość przeżycia całkowitego, ale chore operowane w okresie późniejszym niż 3 miesiące od diagnozy miały dłuższy czas wolny od progresji choroby.
Jedynym wytłumaczeniem dla tej obserwacji jest fakt stosowania przedoperacyjnego leczenia systemowego przez okres kilku miesięcy i dobra odpowiedź na to leczenie, która warunkowała możliwość przeprowadzenia radykalnego leczenia chirurgicznego [27]. Również w pracy Cady'ego i wsp. sekwencja leczenia systemowego i operacyjnego wpływała na wyniki leczenia. Dla chorych, które otrzymały przedoperacyjne leczenie systemowe, 2-letnie przeżycia całkowite wyniosły $90 \%$, ale do leczenia chirurgicznego częściej kwalifikowano chore, u których potwierdzono odpowiedź na chemioterapię [28].

W kilku badaniach autorzy nie potwierdzają wpływu zabiegu operacyjnego na długość przeżycia chorych na raka piersi z synchronicznymi przerzutami odległymi. W pracy Bafford i wsp. porównano wyniki leczenia 147 chorych na raka piersi w IV stopniu zaawansowania, w tym 61 (41\%) operowanych [29]. U 36 chorych rozsiew choroby rozpoznano przed upływem 30 dni od leczenia operacyjnego, a u pozostałych przerzuty stwierdzono przed leczeniem chirurgicznym. Wykazano lepsze przeżycia u chorych, leczonych operacyjnie (HR 0,47), ale zysk ten dotyczył głównie chorych, u których rozsiew choroby rozpoznano już po wykonaniu zabiegu. Średnie przeżycia dla tych chorych wyniosły 4 lata w porównaniu z 2,6 i 2,3 roku u chorych operowanych z potwierdzonym rozsiewem oraz chorych nieoperowanych $(p=0,18)$. Efekt ten można przypisać faktowi, że chore operowane miały mniej zaawansowaną miejscowo chorobę oraz bezobjawowe przerzuty, co powoduje, że z założenia rokowanie dla tych chorych jest lepsze. W kolejnym badaniu, autorstwa Leung i wsp. przeprowadzonym na grupie 157 chorych stwierdzono, że mediana czasu przeżycia w grupie operowanej wyniosła 25 miesięcy w porównaniu z 13 miesiącami u chorych nieleczonych miejscowo $(p=0,004)$. Połowa chorych otrzymała leczenia systemowe. Gdy uwzględniono wpływ leczenia systemowego na przeżycia, okazało się, że samo leczenie miejscowe nie warunkuje wydłużenia przeżycia. Autorzy tłumaczą ten efekt małą liczebnością analizowanej grupy chorych [30]. Autorzy prac podkreślają, że do leczenia operacyjnego kwalifikowano chore młodsze, u których rzadziej rozpoznawano przerzuty odległe w narządach miąższowych oraz u których stwierdzano mniejszą liczbę ognisk przerzutowych [23, 24, 31]. Chore operowane były w lepszym stanie ogólnym, rzadziej były obciążone schorzeniami internistycznymi i również częściej leczono je systemowo (89\% vs 79\%, p =0,0003) [24]. Fakt ten może być przyczyną błędu selekcji chorych, które mając lepsze rokowanie w oparciu o cechy kliniczne, leczone były bardziej agresywnie, co w efekcie skutkowało lepszymi wynikami [28]. W celu ograniczenia wpływu selekcji Cady i wsp. retrospektywnie ocenili 622 chore w IV stopniu zaawansowania, w tym 234 chore leczono operacyjnie, a pozostałe chore (388) nie kwalifikowano do leczenia chirurgicznego, metodą analizy par. W całej grupie stwierdzono dłuższe 
przeżycia całkowite u chorych operowanych ( $p<0,0001$ ). Natomiast analiza, w zależności od lokalizacji przerzutów, wykazała mniejszy wpływ leczenia operacyjnego (dla przerzutów do kości) lub jego brak (przerzuty miąższowe) na przeżycia chorych. Dodatkowa ocena grupy 95 chorych, które przeżyły 5 lat, wskazała na czynniki kliniczne, które mogły wpłynąć na błąd selekcji chorych do leczenia operacyjnego: klasyfikacja zaawansowania klinicznego i włączenie chorych w III stopniu zaawansowania, większy udział chorych z nadekspresją receptorów estrogenowych, z oligometastatyczną postacią choroby i z lokalizacją przerzutów w kościach [28].

W zaleceniach dotyczących roli leczenia operacyjnego u chorych na uogólnionego raka piersi z roku 2011 znalazł się zapis, że największą korzyść z leczenia odniosą chore młode z pojedynczą lokalizacją przerzutu. Zakres leczenia operacyjnego może obejmować zarówno amputację, jak i leczenie oszczędzające, pod warunkiem uzyskania mikroskopowej radykalności [32]. Zmiana w sposobie myślenia o leczeniu miejscowym guza pierwotnego w chorobie pierwotnie uogólnionej znajduje odzwierciedlenie w praktyce klinicznej mimo braku wyników randomizowanych badań. W danych statystycznych Memorial Sloan Kettering Cancer Center z roku 2008 obserwuje się zmniejszenie liczby amputacji piersi wykonywanych w celu łagodzenia objawów klinicznych choroby miejscowej, tzw. zabiegów „objawowych", z 41\% do 25\% na korzyść zabiegów radykalnych, mających na celu zwiększenie przeżyć (zabiegi typu local control). Częstość tych ostatnich wzrosła blisko dwukrotnie, z 34\% do 64\% [33].

W 2013 roku opublikowano wyniki metaanalizy obejmującej 28693 chore na raka piersi w IV stopniu zaawansowania. Leczenie chirurgiczne guza pierwotnego przeprowadzono u 52,8\% chorych. Związane ono było z wydłużeniem przeżyć: $40 \%$ vs $22 \%$ odpowiednio dla pacjentek operowanych i nieleczonych chirurgicznie $(p<0,01)$ [34]. Efekt ten był niezależny od lokalizacji przerzutów, statusu receptorowego i stopnia złośliwości. Wskazano natomiast na możliwą selekcję chorych do leczenia operacyjnego, ponieważ te z mniejszym zaawansowaniem guza pierwotnego, z mniejszą liczbą ognisk przerzutowych i nieobciążone schorzeniami towarzyszącymi częściej były kwalifikowane do zabiegu [34].

\section{Radioterapia}

Radioterapia jest uznaną metodą leczenia miejscowego, stwarzającą możliwość zachowania piersi. Kilka publikacji ocenia wpływ samodzielnej radioterapii na przeżycia chorych [3, 5, 35]. Badanie Le Scodana i wsp. oparte na retrospektywnej analizie 581 chorych na raka piersi z cechą M1(TxNxM1), leczonych w okresie 1984-2004 w Centre Rene Huguenin, Saint-Cloud, z czego u 320 (55\%) zastosowano leczenie miejscowe guza pierwotnego polegające na: wyłącznej radioterapii (u 249 chorych), leczeniu operacyjnym z uzupełniającą radioterapią (u 41 chorych) oraz samodziel- nej chirurgii (u pozostałych 30). Radioterapia polegała na napromienianiu całej piersi, węzłów chłonnych dołu pachowego i węzłów nadobojczykowych do dawek w zakresie 45-50 Gy/g. U ponad 60\% podano dodatkową dawkę na guz pierwotny w zakresie 9-40 Gy (średnio 22,9 Gy/g). Większość chorych otrzymała również leczenie systemowe: chemioterapię (15\%), hormonoterapię (29\%) lub skojarzenie obydwu (52,8\%). U chorych, u których zastosowano leczenie miejscowe, chorobę rozpoznano w niższym stopniu zaawansowania w zakresie guza i węzłów chłonnych, z mniejszą liczbą ognisk przerzutowych oraz przerzutami rzadziej zlokalizowanymi w narządach trzewnych. Częściej u nich stosowano również skojarzone leczenie systemowe. Przeżycia całkowite w całej grupie 1-, 3-, i 5-letnie wyniosły odpowiednio 73\%, 36\% i $17 \%$. Dla chorych, u których przeprowadzono leczenie miejscowe, mediana czasu przeżycia wyniosła 32 miesiące, a przeżycia 3-letnie - 43\% w porównaniu z 21 miesiącami i 26-procentami u chorych bez leczenia miejscowego. Zastosowanie leczenia miejscowego wiązało się ze zmniejszeniem ryzyka zgonu o 30\% w analizie wieloczynnikowej (HR 0,7; p < 0,002). Autorzy przeprowadzili również analizę wpływu radioterapii na przeżycia w zależności od lokalizacji i liczby ognisk przerzutowych. W przypadku przerzutów w narządach miąższowych zastosowanie leczenia miejscowego prowadziło do wydłużenia mediany czasu przeżycia z 13 do 25 miesięcy, a przeżyć 3-letnich - z 17\% do 34\% $(p=0,005)$. U chorych z mnogimi lokalizacjami przerzutów również stwierdzono korzystny efekt radioterapii. Mediana czasu przeżycia i 3-letnie przeżycia wzrosły odpowiednio z 13 do 26 miesięcy i z 12,3\% do 27,7\%. Nie stwierdzono natomiast wpływu radioterapii na przeżycia chorych z izolowanymi przerzutami do kości. W analizie wieloczynnikowej określono czynniki wpływające na przeżycia chorych i obok wieku chorych, zaawansowania klinicznego, leczenia systemowego, liczby i lokalizacji przerzutów istotne okazało się również zastosowanie leczenia miejscowego (HR 0,7) $[3,5]$. Kolejna praca z Instytutu Gustave Roussy'ego potwierdziła rolę radioterapii jako leczenia miejscowego guza pierwotnego [35]. Retrospektywnie analizowano wyniki leczenia u 239 chorych na raka piersi z synchronicznymi przerzutami odległymi, u których zastosowano leczenie miejscowe choroby, z czego samodzielną radioterapię otrzymało 147 chorych (grupa 1), a u 92 pierwszym etapem była operacja, przy czym w tej grupie u 64 chorych zastosowano radioterapię pooperacyjną (grupa 2). Do leczenia miejscowego w większości zakwalifikowano chore z pojedynczym ogniskiem przerzutowym i z lokalizacją pozatrzewną przerzutów. Radioterapia polegała na napromienianiu piersi ze ścianą klatki piersiowej i układu chłonnego do dawek całkowitych $30 \mathrm{~Gy} / \mathrm{g}$ w 10 dfx lub $50 \mathrm{~Gy} / \mathrm{g}$ we frakcjonowaniu konwencjonalnym. Samodzielna radioterapia pozwoliła na uzyskanie długotrwałej kontroli miejscowej u 85\% chorych [34]. Niestety, autorzy pracy nie umieścili informacji o czę- 
Tabela II. Mediana czasu przeżycia i trzyletnie przeżycia całkowite chorych w zależności od rodzaju leczenia miejscowego guza pierwotnego [5]

\begin{tabular}{lcccc}
\hline & RT & S + RT & S & p \\
\hline $\begin{array}{l}\text { Mediana } \\
\text { przeżycia }\end{array}$ & 31 miesięcy & 39 miesięcy & 26 miesięcy & 0,07 \\
3-letnie OS & $41 \%$ & $52 \%$ & $46 \%$ & \\
\hline RT — radioterapia, S - chirurgia, S + RT — chirurgia i radioterapia
\end{tabular}

stości nawrotów u chorych leczonych operacyjnie. Trzyletnie przeżycia bez progresji rozsiewu (MPFS) i przeżycia całkowite (OS) dla chorych napromienianych i leczonych operacyjnie (z ew. uzupełniającą radioterapią) wyniosły odpowiednio $20 \%$ i 39\% oraz 39\% i 57\%. Niezależnymi czynnikami prognostycznymi dla MPFS okazały się być liczba ognisk przerzutowych (HR 1,75) oraz ujemny status receptorowy (HR 3,22), a dla OS - starszy wiek pacjentek (HR 1,46) oraz brak ekspresji receptorów (HR 4,17).

\section{Radioterapia pooperacyjna}

Niewiele jest publikacji, które oceniałyby rolę uzupełniającej pooperacyjnej radioterapii i jej wpływ na przeżycia. W dostępnych publikacjach opisywany efekt tej formy radioterapii jest trudny do interpretacji z uwagi na brak informacji, czy leczenie promieniami stosowane było na obszar blizny pooperacyjnej czy na ogniska przerzutowe. W pracy Le Scodana i wsp. wyodrębniono grupy chorych, które leczono wyłącznie operacyjnie (30 chorych - 9\%) oraz u których po zabiegu chirurgicznym zastosowano radioterapię - 41 chorych (13\%). Mediana czasu przeżycia oraz 3-letnie przeżycia dla tych pacjentek wyniosły odpowiednio 26 miesięcy i 46\% oraz 39 miesięcy i 52\% [5]. Wyniki leczenia chorych w zależności od rodzaju leczenia miejscowego przedstawiono w tabeli II [5].

Na Konferencji ASTRO 2011 przedstawiono doniesienia z Vancouver z Kanady, w którym autorzy ocenili wpływ leczenia miejscowego na przeżycia chorych na raka piersi w IV stopniu zaawansowania w chwili diagnozy. Z grupy 733 chorych u 52 \% zastosowano leczenie miejscowe, które polegało na zabiegu chirurgicznym (u 67\%), radioterapii samodzielnej (u 22\%), a u pozostałych chorych — skojarzone leczenie operacyjne $z$ radioterapią pooperacyjną. Pięcioletnie OS dla chorych nieleczonych i leczonych miejscowo wyniosło odpowiednio $14 \%$ i $21 \%(p<0,004)$. Nie stwierdzono różnic w przeżyciach w zależności od metody leczenia miejscowego. W analizie jednoczynnikowej wykazano, że parametrami klinicznymi, które w istotny sposób wpłynęły na 5-letnie przeżycia, są: wiek < 50 rż., stan sprawności wg ECOG 0-1, obecność receptorów steroidowych, pojedyncze ognisko przerzutowe oraz lokalizacja przerzutów w kościach. Natomiast w analizie wieloczynnikowej wykazano, że leczenie miejscowe, niezależnie od rodzaju, zmniejszało ryzyko zgonu (HR 0,78) w równym stopniu jak zastosowane leczenie systemowe (chemioterapia HR 0,82 i hormonoterapia $\mathrm{HR} 0,69)[36,37]$.

Zasadnym wydaje się pytanie, czy zastosowanie leczenia miejscowego (operacyjnego czy radioterapii) rzeczywiście powoduje istotną poprawę wyników leczenia chorych na pierwotnie uogólnionego raka piersi, czego wyrazem jest wydłużenie przeżycia średniego oraz całkowitego, czy być może popełniamy błąd w selekcji chorych, które w oparciu o cechy kliniczno-patologiczne, mając lepsze rokowanie, otrzymują przez to bardziej agresywne leczenie, którego wyniki są lepsze [38, 39]. W pracach oceniających zarówno rolę leczenia operacyjnego, jak i rolę radioterapii, zauważamy, że chore, które otrzymały leczenie miejscowe, były młodsze, w lepszym stanie ogólnym, z mniej zaawansowaną miejscowo chorobą, z mniejszą liczbą ognisk przerzutowych oraz z rozpoznaniem guzów hormonozależnych. Wszyscy autorzy podkreślają w dyskusji możliwość niezamierzonego błędu selekcji chorych oraz wskazują na konieczność oparcia ostatecznych wniosków na analizie badań randomizowanych, dlatego w pełni uzasadnione było zaprojektowanie i rozpoczęcie badań $[3-5,7,10,24]$. Aktualnie prowadzonych jest kilka randomizowanych badań klinicznych [32].

1. Analysis of Surgery in Patients Presenting With Stage IV Breast Cancer prowadzone w Memorial Sloan-Kettering Cancer Center. Rekrutację do badania rozpoczęto w $2009 \mathrm{r}$.

2. POSYTIVE (Primary Operation in Synchronous meTastasized InVasivE Breast Cancer) w ośrodku uniwersyteckim w Wiedniu, rozpoczęte w maju $2010 \mathrm{r}$.

3. $\mathrm{NCl}$ - Early Surgery or Standard Palliative Therapy in Treating Patients With Stage IV Breast Cancer.

4. Turkish Federation of National Societies for Breast Diseases, w którym planowane było włączenie 271 chorych dla porównania wyników pierwotnego leczenia chirurgicznego z następowym leczeniem systemowym oraz pierwotnego leczenia systemowego z leczeniem operacyjnym zarezerwowanym dla postępowania paliatywnego. Zakończenie rekrutacji do tego badania planowane było do końca 2012 roku [40].

5. Tata Memorial Hospital w Indiach, do którego planowano włączenie 350 chorych, które po wstępnej chemioterapii z zastosowaniem antybiotyków antracyklinowych kwalifikowane były do leczenia miejscowego (leczenie operacyjne z radioterapią) lub do obserwacji. Zakończono rekrutację chorych.

6. SUBMIT (Systemic therapy with or without up front surgery of the primary tumor in breast cancer patients with distant metastases at initial presentation) - wieloośrodkowe badanie holenderskie rozpoczęte w 2011 roku [41].

7. PRIM-BC - badanie prowadzone przez japońska grupę JCOG1017- porównuje leczenie operacyjne guza pierwotnego z samodzielnym leczeniem systemowym u chorych na raka piersi w IV stopniu zawansowania, które odpowiedziały na pierwotne leczenie systemowe [42]. 
Dla wielu chorych na raka piersi w stadium pierwotnego rozsiewu zasadne jest podjęcie bardziej agresywnego leczenia w celu uzyskania długotrwałych wyleczeń, wydłużenia życia i poprawy jego jakości. W erze nowoczesnych możliwości leczenia systemowego oraz związanej z nim korzyści klinicznej w pełni uzasadniona wydaje się być zmiana w podejściu do leczenia miejscowego pierwotnej choroby. Pozostaje pytanie o to, które chore odniosą największą korzyść z agresywnego leczenia miejscowego oraz jaki jest optymalny czas leczenia oraz czy możliwy jest wybór metody leczenia. Czy jest zatem czas na zmianę kryteriów operacyjności chorych na raka piersi w stadium uogólnienia?

\section{Konflikt interesu: nie zgłoszono}

\section{Dr Elżbieta Nowicka}

III Klinika Radioterapii i Chemioterapii

Centrum Onkologii — Instytut im. M. Skłodowskiej-Curie

Oddział w Gliwicach

ul. Wybrzeże Armii Krajowej 15, 44-101 Gliwice

e-mail:enowicka@io.gliwice.pl

\section{Otrzymano: 17 grudnia $2012 \mathrm{r}$.}

Przyjęto do druku: 27 sierpnia $2013 \mathrm{r}$.

\section{Piśmiennictwo}

1. SEER data base. http://seer.cancer.gov/statfacts/html/breast.html.

2. American Cancer Society Breast Cancer Facts and Figures 2011-2012 http://www.cancer.org.

3. Le Scodan R, Ali D, Stevens D. Exclusive and adjuvant radiotherapy in breast cancer patients with synchronous metastases. BMC Cancer 2010; 10:630.

4. Ali $D$, Le Scodan R. Treatment of the primary tumour in breast cancer patients with synchronous metastases. Ann Oncol 2011; 22: 9-16.

5. Le Scodan R, Stevens D, Brain E i wsp. Breast cancer with synchronous metastases: survival impact of exclusive localregional radiotherapy. $J$ Clin Oncol 27:1375-1381.

6. Zemła BFP, Banasik TR, Tomaka A i wsp. Epidemiologia nowotworów złośliwych piersi w populacji śląskich kobiet. Gliwice: Zakład Epidemiologii Nowotworów Regionalny Śląski Rejestr Nowotworów, Centrum Onkologii — Instytut im. M Skłodowskiej Curie Oddział Gliwice; 2003.

7. Pagani O, Senkus E, Wood W i wsp. International guidelines for management of metastatic breast cancer : can metastatic cancer be cured? J Nat Cancer Inst 2010; 102: 456-463.

8. Andre F, Slimane K, Bachelot T i wsp. Breast cancer with synchronous metastases: trends in survival during a 14 year period. J Clin Onco/ 2004; 22: 3302-3308.

9. Brennan ME, Houssami N. Evaluation of the evidence on staging imaging for detection of asymptomatic distant metastases in newly diagnosed breast cancer. Breast 2012; 21: 112-123.

10. Krzakowski M. Zalecenia postępowania diagnostyczno terapeutycznego w nowotworach złośliwych. Gdańsk: Via Medica, 2011.

11. Babiera GV, Rao R, Feng L i wsp. Effect of primary tumor extirpation in breast cancer patients who present with stage IV disease and an intact primary tumor. Ann Surg Oncol 2006; 13: 776-782.

12. Gnerlich J, Jeffe DB, Deshpande AD i wsp. Surgical removal of the primary tumor increases overall survival in patients with metastatic breast cancer: analysis of the 1988-2003 SEER data. Ann Surg Onol 2007; 14: 2187-2194.

13. Ruiterkamp J, Voogd AC, Bosscha K i wsp. Impact of breast surgery on survival in patients with distant metastases at initial presentation: a systemic review of the literature. Breast Cancer Res Treat 2010; 120: 9-16.

14. Flanigan RC, Salmon SE, Blumenstein BA i wsp. Nephrectomy followed by interferon alfa- $2 \mathrm{~b}$ compared with interferon alfa- $2 \mathrm{~b}$ alone for metastatic renal-cell cancer. N Engl J Med 2001; 345: 1655-1659.

15. Fehm T, Sagalowsky A, Clifford E i wsp. Cytogenetic evidence that circulating epithelial cells in patients with carcinoma are malignant. Clin Cancer Res 2002; 8: 2073-2084.

16. Cristofanilli M, Budd GT, Ellis MJ i wsp. Circulating tumor cells, disease progression, and survival in metastatic breast cancer. NEng/ J Med 2004; 351: 781-791.
17. Cristofanilli M, Hayes DF, Budd GT i wsp. Circulating tumor cells: a novel prognostic factor for newly diagnosed metastatic breast cancer. J Clin Oncol 2005; 23: 1420-1430.

18. Caras I, Grigorescu A, Stavaru C i wsp. Evidence for immune defects in breast and lung cancer patients. Cancer Immunol Immunother 2004; 53 : $1146-1152$

19. Danna EA, Sinha P, Gilbert M i wsp. Surgical removal of primary tumor reverses tumor-induced immunosuppression despite the presence of metastatic disease. Cancer Res 2004; 64: 2205-2211.

20. Overgaard M, Jensen MB, Overgaard J i wsp. Postoperative radiotherapy in high-risk postmenopausal breast-cancer patients given adjuvant tamoxifen: Danish Breast Cancer Cooperative Group DBCG 82c randomised trial. Lancet 1999; 353: 1641-1648.

21. Clarke M, Collins R, Darby Si wsp. Effects of radiotherapy and of differences in the extent of surgery for early breast cancer on local recurrence and 15-year survival: an overview of the randomised trials. Lancet 2005; 366: 2087-2106.

22. Demicheli R, Retsky MW, Hrushesky WJ i wsp. The effects of surgery on tumor growth: a century of investigations. Ann Oncol 2008; 19: 1821-1828.

23. Khan SA, Stewar AK, Morrow M i wsp. Does aggressive local therapy improve survival in metastatic breast cancer? Surgery 2002; 132: 626-627.

24. Ruiterkamp J, Ernst MF, van de Poll-Franse LV i wsp. Surgical resection of the primary tumour is associated with improved survival in patients with distant metastatic breast cancer at diagnosis. Eur J Surg Oncol 2009; 35: $1146-1151$.

25. Rapiti E, Verkooijen HM, Vlastos G i wsp. Complete excision of primary breast tumor improves survival of patients with metastatic breast cancer at diagnosis. J Clin Oncol 2006; 24: 2743-2749.

26. Shien T, Kinoshita T, Shimizu C i wsp. Primary tumor resection improves the survival of younger patients with metastatic breast cancer. Oncol Rep 2009; 21: 827-832.

27. Rao R, Feng L, Kuerer HM i wsp. Timing of surgical intervention for the intact primary in stage IV breast cancer patients. Ann Surg Oncol 2008; 15: 1696-1702.

28. Cady B, Nathan NR, Michaelson JS i wsp. Matched pair analyses of stage IV breast cancer with or without resection of primary breast site. Ann Surg Oncol 2008; 15: 3384-3395

29. Bafford AC, Burstein HJ, Barkley CR i wsp. Breast surgery in stage IV breast cancer: impact of staging and patient selection on overall survival. Breast Cancer Res Treat 2009; 115: 7-12.

30. Leung AM, Vu HN, Nguyen KA i wsp. Effects of surgical excision on survival of patients with stage IV breast cancer. J Surg Res 2010; 161: 83-88.

31. Ruiterkamp J, Ernst MF, de Munck L i wsp. Improved survival of patients with primary distant metastatic breast cancer in the period of 1995 -2008 . A nationwide population-based study in the Netherlands. Breast Cancer Res Treat 2011; 128: 495-503.

32. Ruiterkamp J, Ernst MF. The role of surgery in metastatic breast cancer. Eur Journal of Cancer 2011; 47 Supp 3: S6-S22.

33. Morrogh M, Park A, Norton N i wsp. Changing indications for surgery in patients with stage IV breast cancer: a current perspective. Cancer 2008; 112: 1445-1454.

34. Harris E, Barry M, Kell MR. Metaanalysis to determine if surgical resection of the primary tumor in the setting of stage IV breast cancer impact on survival. Ann Surg Oncol 2013; 20: 2828-2834.

35. Bourgier C, Khodari W, Vataire AL i wsp. Breast radiotherapy as part of loco-regional treatments in stage IV breast cancer patients with oligometastatic disease. Radiother Oncol 2010; 96: 199-203.

36. Nguyen D. Can locoregional treatment of the primary tumor improve outcomes for women with stage IV breast cancer at diagnosis? Int J Radiat Oncol Biol Phys 2012; 84, 39-45.

37. Nguyen DH, Truong PT, Walter CV i wsp. Limited M1 disease: a significant prognostic factor for stage IV breast cancer. Ann Surg Oncol 2012; 19: 3028-3034.

38. Khan S.A. Primary tumor resection in stage IV breast cancer: consistent benefit or consistent bias? Ann of Surgical Oncology 2007; 14: 3285-3287.

39. Chang DY, Lin CH, Lu YS. Locoregional therapy improves survival for metastatic breast cancer patients? Benefit remains questionable! $J$ Clin Oncol 2009; 27: e179.

40. Soran A, Ozbas S, Kelsey SF i wsp. Randomized trial comparing locoregional resection of primary tumor with no surgery in stage IV breast cancer at the presentation (Protocol MF07-01): a study of Turkish Federation of the National Societies for Breast Diseases. Breast J 2009; 15: 399-403.

41. Ruiterkamp J, Voogd AC, Tjan-Heijnen VC i wsp. SUBMIT: Systemic therapy with or without up front surgery of the primary tumor in breast cancer patients with distant metastases at initial presentation. BMC Surg 2012; 12: 5 .

42. Shien $\mathrm{T}$, Nakamura $\mathrm{K}$, Shibata $\mathrm{T}$ i wsp. A randomized controlled trial comparing primary tumour resection plus systemic therapy with systemic therapy alone in metastatic breast cancer (PRIM-BC): Japan Clinical Oncology Group Study JCOG1017. Jpn J Clin Oncol 2012; 42: 970-973. 